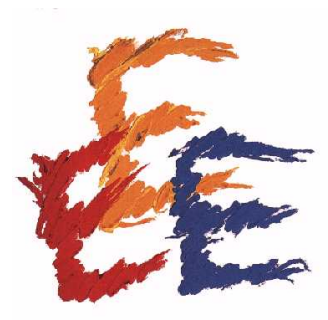

Fondazione Eni Enrico Mattei

\title{
Climate Change and Water Resources in the Middle East: Vulnerability, Socio-Economic \\ Impacts, and Adaptation
}

M. El-Fadel* and E. Bou-Zeid**

NOTA DI LAVORO 46.2001

\section{JUNE 2001}

NRM - Natural Resources Management

*Department of Civil and Environmental Engineering, American University of Beirut, Beirut, Lebanon

** Department of Geogr. \& Envir. Engineering, Johns Hopkins University, Baltimore, Maryland

This paper can be downloaded without charge at:

The Fondazione Eni Enrico Mattei Note di Lavoro Series Index: http://www.feem.it/web/activ/_activ.html

Social Science Research Network Electronic Paper Collection: http://papers.ssrn.com/abstract=278514 


\title{
Climate Change and Water Resources in the Middle East: Vulnerability, Socio-Economic Impacts, and Adaptation ${ }^{\text {a }}$
}

\author{
M. El-Fadel ${ }^{* b}$ and E. Bou-Zeid ${ }^{c}$
}

\section{INTRODUCTION}

Climate change due to greenhouse gases (GHG) has been at the forefront of current research efforts in the past decade (IPCC-WGI 1996a, 1996b). The aim of these efforts was defined at the Earth Summit in Rio de Janeiro as achieving "stabilization of greenhouse gas concentrations in the atmosphere at a level that would prevent dangerous anthropogenic interference with the climatic system". This statement of purpose clearly recognizes that some change is inevitable and acceptable as long as it is not considered dangerous. However, the real challenge is to predict how GHGs interfere with the climatic system and what impacts will result. In this context, several modeling approaches have been used to simulate climate conditions under increased $\mathrm{CO}_{2}$ concentration. The models vary from simple upwelling diffusion-energy balance models to complex General Circulation Models (GCMs) with atmospheric and ocean modules (AOGCM) (IPCC-WGI 1996a). However, many aspects, critical to climate modeling, are still not fully understood including cloud physics, aerosol effect, and atmosphere-ocean interaction among other processes (IPCC-WGI 1996a, IHS 1999).

A critical factor hindering the development of accurate predictions for future weather is the uncertainty inherent in estimating GHG emissions and concentrations. In addition to GHG concentrations, several other factors are important for climate modeling such as aerosol concentrations. The localized cooling effect of aerosols is considered as an important aspect that cannot be neglected in climate change models (IHS 1999, IPCC-TGCIA 1999, IPCC-WGII 1997). Despite uncertainties, GCMs depict certain trends that are useful in analyzing vulnerability and setting guidelines for potential adaptation measures. GCM simulations generally indicate increasing global temperatures leading to a more active hydrologic cycle. An increase in the hydrologic cycle activity denotes increasing global evaporation and precipitation. For the Middle East, GCM simulations indicate higher future temperatures that will increase evapotranspiration and changes in climate patterns that might reduce rainfall in the region as a whole (IPCC-DCC 1999, IPCC-WGI 1996a).

This paper evaluates climate change scenarios for the Middle East. For this purpose, simulations from several GCMs were used. Socio-economic implications of the projected impacts are outlined and adaptation measures are addressed in the context of regional characteristics.

\section{CLIMATE CHANGE AND WATER RESOURCES}

Vulnerability of water systems and their sensitivity to climate change have been an active research topic in the last decade (Arnell 1996, IHS 1999). In view of the uncertainties associated with climate and hydrologic models, the benefits of developing quantified predictions remain controversial (IPCC-WGII 1996). Water resources management systems are very adaptive by nature (or through institutional intervention) and the usual variations in climatic and socio-economic conditions have provided water managers with experiences that help them cope with potential changes in climate patterns (Strzepek

\footnotetext{
${ }^{\text {a }}$ Portions of this paper have been accepted for publication in ASCE, Journal of Water Resources Planning and Management

* Correspondence author:

Department of Civil and Environmental Engineering, Faculty of Engineering \& Architecture

American University of Beirut, Bliss Street, PO Box 11-0236, Beirut, Lebanon

Tel: 961-3-228 338. Fax +961-1-744 462. Email: MFADEL@AUB.EDU.LB

${ }^{\mathrm{b}}$ Associate Professor, Dept. of Civ. \& Envir. Engrg., American Univ. of Beirut, Beirut, Lebanon

${ }^{\mathrm{c}}$ Graduate Student, Dept. of Geogr. \& Envir. Engrg., Johns Hopkins Univ., Baltimore, Maryland
} 
1998). However, the high rate of climate change and its cumulative effect might pose serious problems. Some biophysical and socio-economic impacts on water resources expected with a potentially changing climate are summarized in Table 1.

Table 1. Some impacts on water resources expected with changing climate

\begin{tabular}{l|l|l}
\hline Biophysical aspects & Major impacted components & Some potential effects \\
\hline Hydrologic parameters & $\partial$ Precipitation & $\partial$ Soil moisture changes \\
& $\partial$ Evaporation & $\partial$ Reduced ground water recharge \\
& $\partial$ Transpiration & $\partial$ Water shortages or surpluses \\
& $\partial$ Runoff & $\partial$ Dam failure due to floods \\
& $\partial$ Recharge & $\partial$ Dam storage loss due to sedimentation \\
\hline \multirow{2}{*}{ Water quality } & $\partial$ Water temperature & $\partial$ Changes in chemical quality \\
& $\partial$ Water salinity & $\partial$ Changes in biological quality \\
& $\partial$ Pollutant concentrations & $\partial$ Changes in thermal quality \\
& $\partial$ Fauna and flora & \\
\hline Aquatic systems & $\partial$ Streamflows & $\partial$ Droughts or floods \\
& $\partial$ Erosion and sedimentation & $\partial$ Dam failure due to floods \\
& $\partial$ Water levels in surface water bodies & $\partial$ Dam storage loss due to sedimentation \\
& $\partial$ Water levels in aquifers & \\
\hline \multirow{2}{*}{ Socio-economic aspects } & $\partial$ Water fluxes in the subsurface & \\
\hline Water supply & & \\
& $\partial$ Water demand per capita & $\partial$ Water demand increase beyond projected \\
& $\partial$ Agricultural water demand & levels \\
\hline Water management systems & $\partial$ Streamflows & $\partial$ Reduced water supply \\
& $\partial$ Water level in surface water bodies & $\partial$ Changing loads on water treatment systems \\
& $\partial$ Water levels in aquifers & $\partial$ Changing hydropower production potential \\
\hline
\end{tabular}

\section{WATER RESOURCES IN THE MIDDLE EAST}

The borders of the "Middle East" are not well established. The boundaries of this region change with changing topics. A different approach in defining the area is used in politics, geography, history, environment, economics, etc. For the scope of this paper, the countries that have significantly interconnected water resources and that do not yet rely heavily on desalination techniques are considered. That is: Lebanon, Syria, Iraq, Israel, Jordan, and the Palestinian Authority (West Bank and Gaza Strip) (Figure 1). While Turkey is the source of a significant amount of water flowing into Iraq and Syria, it is not addressed in this study due to climatic and hydrologic differences with the countries under consideration. 


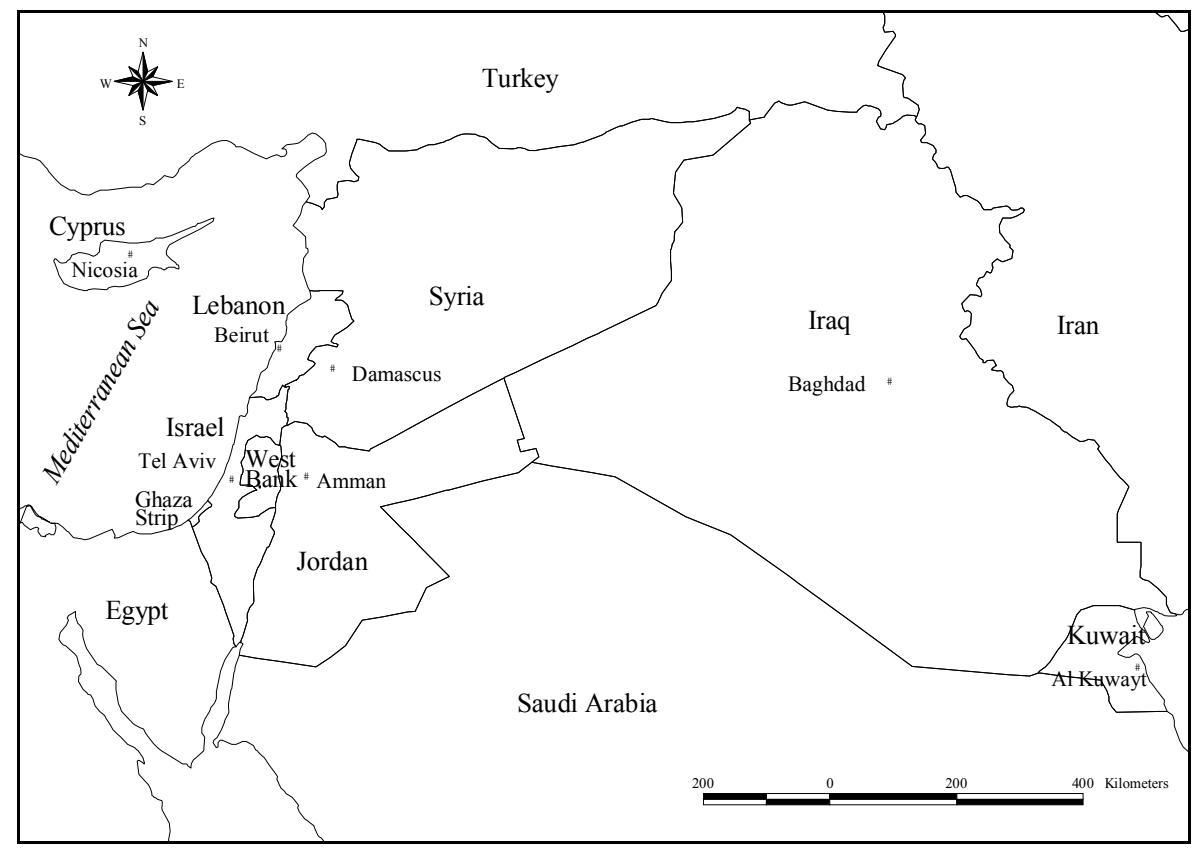

Figure 1. Map of Middle Eastern countries considered in this study

The Middle East and North Africa, with water resources of less than 1,000 $\mathrm{m}^{3}$ per capita in 9 out of 14 countries, is the part of the world where water scarcity is the most severe and precarious (Berkoff 1994, ESCWA 1996, ESCWA 1999, Postel 1993). Water shortage and uneven distribution of water supply are exacerbated by the rapid demographic and economic development in the region (Figure 2 and Table 2) increasing water demand at a relatively high pace. Iraq is the only other country in the Middle East that appears to have sufficient water resources at present. However, unlike Lebanon, Iraq is at the disadvantage of procuring more than two-thirds of its water resources as river flows from Turkey (Berkoff 1994).

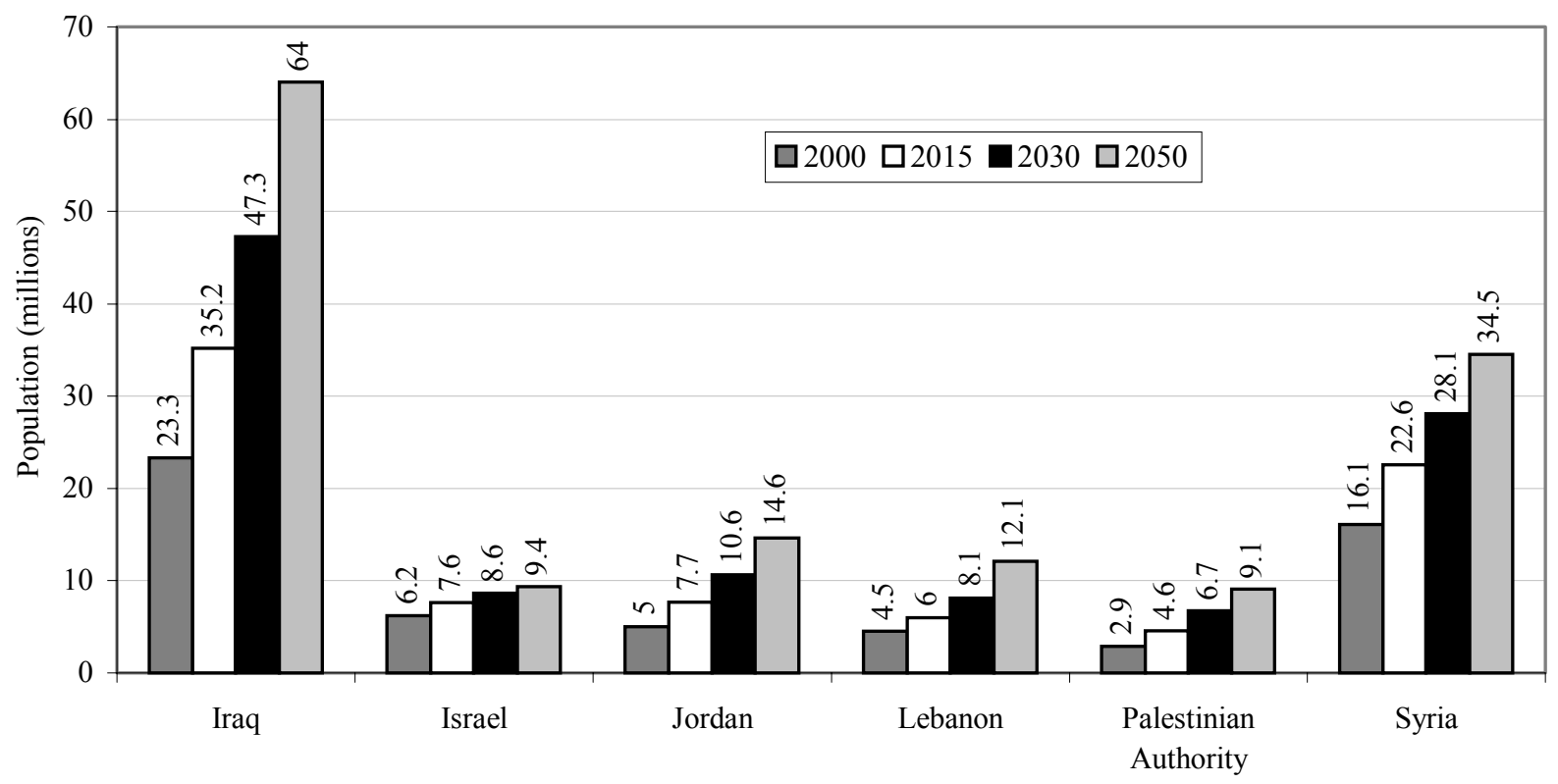

Figure 2. Population projections

(Berkoff 1994, ESCWA 1999, FAOSTAT 1999, El-Fadel et al. 2000) 
Table 2. Socio-economic indicators (Encyclopædia Britannica 1999, FAOSTAT 1999, World Bank 1999)

\begin{tabular}{|c|c|c|c|c|c|c|c|}
\hline \multirow[b]{2}{*}{ Country } & \multirow[b]{2}{*}{ Area } & \multirow[b]{2}{*}{$\begin{array}{c}\text { Urban } \\
\text { Population }\end{array}$} & \multirow[b]{2}{*}{ GNP in 98} & \multicolumn{2}{|c|}{ GNP per capita } & \multirow[b]{2}{*}{$\begin{array}{c}\text { GDP growth } \\
99-03\end{array}$} & \multirow{2}{*}{$\begin{array}{l}\text { Access to } \\
\text { safe } \\
\text { drinking } \\
\text { water }\end{array}$} \\
\hline & & & & in 98 & $\begin{array}{c}\text { growth } \\
99-03\end{array}$ & & \\
\hline & $\mathrm{km}^{2}$ & $\%$ of total & Billion US\$ & US\$ & $\%$ & $\%$ & $\%$ of pop \\
\hline Iraq & 438,320 & 76 & $--^{c}$ & 540 & -9.0 & -6.0 & 77 \\
\hline Israel $^{\mathrm{a}}$ & 20,700 & 91 & 95.2 & 15,940 & -0.3 & 2.0 & 99 \\
\hline Jordan & 89,210 & 73 & 6.9 & 1,520 & 0.4 & 3.2 & 98 \\
\hline Lebanon & 10,452 & 89 & 15.0 & 3,560 & 1.7 & 3.5 & 94 \\
\hline $\begin{array}{l}\text { Palestinian } \\
\text { Authority }\end{array}$ & 6,263 & $-{ }^{c}$ & $--^{c}$ & $-{ }^{c}$ & $--^{c}$ & $-{ }^{c}$ & $-{ }^{c}$ \\
\hline Syria & 185,180 & 54 & 15.6 & 1,020 & 2.4 & 4.8 & 88 \\
\hline $\begin{array}{l}\text { a Area contr } \\
{ }^{\mathrm{b}} \text { West Bank } \\
{ }^{\mathrm{c}} \text { Not availal }\end{array}$ & $\begin{array}{l}\text { by Israel b } \\
\text { Gaza Strip }\end{array}$ & ore 1967 & & & & & \\
\hline
\end{tabular}

It is expected that by 2025 the average annual renewable water resources for the Middle East would have fallen to $667 \mathrm{~m}^{3}$ per capita compared to a world average of $4,780 \mathrm{~m}^{3}$ per capita (Berkoff 1994). Projections indicate significant water shortages in the future for most countries in the region (Table 3). Only Iraq would have adequate resources to cover its demands; however, recent Turkish projects on the Euphrates and Tigris rivers threaten to reduce Iraq's supplies significantly. Table 3 depicts the baseline conditions neglecting the effects of potential climate change. These estimates do not account for potential increased capacity in desalination or wastewater reuse. The ranges presented rely on varying assumptions of demographic growth, water use variation, water resources management reform, etc. Table 4 depicts water demand growth for the countries under study. Note that agricultural demand accounts for 84 percent ( 30 to 88 percent for the individual countries) of the water demand in the region.

Table 3. Annual water resources in some Middle Eastern countries (Berkoff 1994, Shuval 1994, FAO 1997, ESCWA 1999, Alatout 2000, Amery 2000, El-Fadel et al. 2000, Lithwick 2000, Shannang and Al-Adwan 2000)

\begin{tabular}{|c|c|c|c|c|c|c|}
\hline \multirow[b]{2}{*}{ Country } & \multirow{2}{*}{$\begin{array}{c}\text { Average } \\
\text { Annual } \\
\text { Rainfall }\end{array}$} & \multirow{2}{*}{$\begin{array}{c}\text { Use of } \\
\text { desalinated } \\
\text { water and } \\
\text { reclaimed } \\
\text { waste water }\end{array}$} & \multirow{2}{*}{$\begin{array}{l}\text { Total } \\
\text { renewable } \\
\text { water } \\
\text { resources }\end{array}$} & \multicolumn{3}{|c|}{$\begin{array}{c}\text { Current and Projected Renewable Water } \\
\text { Resources }\end{array}$} \\
\hline & & & & 1997 & 2015 & 2025 \\
\hline & $m m$ & $\begin{array}{l}\% \text { of total } \\
\text { withdrawal }\end{array}$ & Billion $\mathrm{m}^{3}$ & \multicolumn{3}{|c|}{$m^{3}$ per capita } \\
\hline Iraq & 154 & $--^{a}$ & $\begin{array}{l}62.85- \\
100.00\end{array}$ & $\begin{array}{l}2,963 \\
4,628\end{array}$ & $\begin{array}{l}1,832 \\
2,938\end{array}$ & $\begin{array}{l}1,359 \\
2,000\end{array}$ \\
\hline Israel & 630 & 11.56 & $\begin{array}{l}1.50- \\
2.57\end{array}$ & $\begin{array}{l}280 \\
435\end{array}$ & $\begin{array}{l}190 \\
356\end{array}$ & $\begin{array}{l}140- \\
311\end{array}$ \\
\hline Jordan & 94 & 5.32 & $\begin{array}{l}0.75- \\
1.35\end{array}$ & $\begin{array}{l}168- \\
229\end{array}$ & $\begin{array}{r}78- \\
133\end{array}$ & $\begin{array}{l}70- \\
91\end{array}$ \\
\hline Lebanon & 827 & 0.16 & $\begin{array}{l}2.00- \\
3.94\end{array}$ & $\begin{array}{l}766- \\
1,287\end{array}$ & $\begin{array}{l}336- \\
979\end{array}$ & $\begin{array}{l}262- \\
809\end{array}$ \\
\hline $\begin{array}{l}\text { Palestinian } \\
\text { Authority }\end{array}$ & 350 & 1.08 & $\begin{array}{l}0.20- \\
0.22\end{array}$ & $\begin{array}{l}72- \\
92\end{array}$ & $\begin{array}{l}43- \\
56\end{array}$ & $\begin{array}{l}34- \\
36\end{array}$ \\
\hline Syria & 252 & 2.56 & $\begin{array}{l}15.00- \\
21.48-\end{array}$ & $\begin{array}{l}1,160 \\
1,438\end{array}$ & $\begin{array}{l}759- \\
948\end{array}$ & $\begin{array}{l}535- \\
609\end{array}$ \\
\hline
\end{tabular}


Table 4. Current and projected water demand for the region (Million $\mathrm{m}^{3}$ )

(Berkoff 1994, ESCWA 1999, FAOSTAT 1999, MFA 1999, EL-Fadel et al. 2000)

\begin{tabular}{l|c|c|c|c|c}
\hline \multirow{2}{*}{\multicolumn{1}{c|}{ Country }} & \multicolumn{2}{c|}{$\begin{array}{c}\text { Current and projected total } \\
\text { water demand }\end{array}$} & \multicolumn{2}{c}{ Projected breakdown for 2025 by sectors } \\
\cline { 2 - 6 } & 2000 & 2025 & Domestic & Agriculture & Industrial \\
\hline Iraq & 54,972 & 74,310 & 4,750 & 66,000 & 3,560 \\
Israel & 1,960 & 3,116 & 997 & 1,906 & 206 \\
Jordan & 1,257 & 1,760 & 700 & 900 & 160 \\
Lebanon & 1,650 & 3,069 & 876 & 1,500 & 693 \\
Palestinian Authority & 495 & 1,290 & 800 & 420 & 70 \\
Syria & 17,130 & 23,555 & 2,825 & 19,430 & 1,300 \\
\hline
\end{tabular}

\section{CLIMATE CHANGE IMPACTS ON WATER RESOURCES IN THE MIDDLE EAST}

It is often assumed that since the Middle East region has very scarce water resources and an arid climate, the impact of climate change would be negligible (IPCC-WGII 1996). However, as noted before, water resources in the region are under a heavy and increasing stress. Any alteration in climatic patterns that would increase temperatures and reduce rainfall would greatly exacerbate existing difficulties. The general approach used for assessing the impacts on hydrologic regimes is to obtain climate data (representing various assumptions concerning projection period, GHG growth assumptions, etc.) from GCMs and RCMs and use them as input to basin hydrologic models. However, if long-term data on rainfall-runoff correlation and basin water balance are not available, complex hydrologic models should be avoided (IHS 1999, IPCC-WGI 1996b, Strzepek 1998). Such data are unfortunately missing or unavailable in almost all the countries under study (Lonergan and Brooks 1994, IDRC 2000). While data are available for some major basins, data collection programs are recent and do not have the time span that allows reliable statistical correlations of inputs (precipitation, runon, etc.) and outputs (runoff, evaporation, etc.) to be developed for extreme conditions. Therefore, potential climate change impacts are evaluated using GCM simulations.

Several GCMs have been used to model future climate for the whole planet under varying scenarios. Recent efforts focused on setting standard scenarios and time-frames to ensure comparability of results from different GCM simulations (Strzepek 1998, IPCC-WGI 1996a, IPCC-WGII 1997). GCMs relative success in reproducing global weather patterns from past data is not necessarily an assurance that they will correctly predict future climate even at the global scale.

Climate change projections in the Middle East are compared using simulation results from four different GCMs (ECHAM4, HadCM2, CGCM1, GFDL) for the same set of assumptions (IS92a scenario). Both greenhouse gases and sulfur aerosols are accounted for in the GCMs and the projections available are for the 2020s climate conditions in comparison to the period 1961-1990.

The temperature change during the winter (January, February, March) and the summer (June, July, August), and the rainfall change during the wet season (October to April) as calculated by the different models for the countries under study are summarized in Table 5. These results show minor changes in mean precipitation for the region, while temperatures are projected to increase in all seasons. Mean summer temperatures, already high in the region, will rise significantly $\left(0.8-2.1{ }^{\circ} \mathrm{C}\right)$. Areas bordering the Mediterranean (Lebanon, Israel, Palestinian Authority, coastal Syria) would be the least affected. However, ground water aquifers in these areas will be under the hazard of increased seawater intrusion due to higher sea levels.

The discrepancies between predictions of different models reach a maximum $1.3{ }^{\circ} \mathrm{C}$ for Syria during the summer. However, the trend is clearly towards increasing mean temperatures. This will increase irrigation water demand due to higher evaporation. Extreme temperatures are predicted to increase more than mean temperature values. Increased temperature and evapo-transpiration coupled with 
constant precipitation are highly associated with desertification. Mean winter temperatures will also increase; however, the rise is lower than for the summer season. Higher winter temperatures will enhance evapotranspiration and reduce potential groundwater recharge. If the increased runoff due to sharper precipitation patterns is also considered, the net effect will be a reduction in groundwater recharge and hence in the baseline renewable water resources (Table 3).

It is noteworthy that while most models predicted an increase in temperature, few reported an opposite trend. One particular study that coupled a nested regional model for the Middle East and southern Europe to a GCM predicted a decrease in temperature for the region ranging from 0 to $1{ }^{\circ} \mathrm{C}$ due to doubling $\mathrm{CO}_{2}$ levels (Jones et al. 1997). This was attributed to sulfur aerosols cooling effect.

Table 5. Climate change parameters (IPCC-DCC 1999)

\begin{tabular}{lc|c|c|c|c|c}
\hline \multicolumn{7}{c}{ January-March mean temperature increase $\left({ }^{\circ} \mathrm{C}\right)$} \\
\hline \multicolumn{1}{c|}{ Country } & HadCM2 & GFDL-R15 & CGCM & Echam4 & $\Delta$ T max \\
\hline Iraq & 0.9 & 1.7 & 1.6 & 1.1 & 1.7 \\
Israel & 0.6 & 1.2 & 1.2 & 1 & 1.2 \\
Jordan & 0.9 & 1.8 & 1.3 & 1.1 & 1.8 \\
Lebanon & 0.6 & 1.2 & 1.3 & 1 & 1.3 \\
Palestine & 0.6 & 1.2 & 1.3 & 1 & 1.3 \\
Syria & 0.8 & 1.7 & 1.3 & 1.1 & 1.7 \\
\hline
\end{tabular}

June-August mean temperature increase $\left({ }^{\circ} \mathrm{C}\right)$

\begin{tabular}{|c|c|c|c|c|c|}
\hline Country & HadCM2 & GFDL-R15 & $C G C M$ & Echam 4 & $\Delta T \max$ \\
\hline Iraq & 0.9 & 2.1 & 1.5 & 1.5 & 2.1 \\
\hline Israel & 0.8 & 1.8 & 0.9 & 1.4 & 1.8 \\
\hline Jordan & 0.9 & 2.1 & 0.8 & 1.2 & 2.1 \\
\hline Lebanon & 0.8 & 1.8 & 0.9 & 1.4 & 1.8 \\
\hline Palestine & 0.8 & 1.8 & 0.9 & 1.2 & 1.8 \\
\hline Syria & 0.8 & 2.1 & 0.8 & 1.2 & 2.1 \\
\hline
\end{tabular}

October-April mean rainfall change ( $\mathrm{mm} /$ day)

\begin{tabular}{l|c|c|c|c|c}
\hline \multicolumn{1}{c|}{ Country } & HadCM2 & GFDL-R15 & CGCM & Echam4 & $\Delta$ P max \\
\hline Iraq & 0 & 0 & 0 & 0 & 0 \\
Israel & 0 & -0.1 & 0 & 0 & -0.1 \\
Jordan & 0 & 0 & 0 & 0 & 0 \\
Lebanon & 0 & -0.1 & 0 & 0 & -0.1 \\
Palestine & 0 & -0.1 & 0 & 0 & -0.1 \\
Syria & 0 & 0 & 0 & 0 & 0 \\
\hline
\end{tabular}

Note: Values are for 2020 s relative to the $1961-1990$ period

\section{SOCIO-ECONOMIC IMPLICATIONS}

One of the main targets of vulnerability studies is to relate potential impacts on biophysical environments to the socio-economic effects resulting from such impacts. The simplest approaches attempt to establish and assess the direct linkages between the biophysical setting and the economic activity. Consequently, the socio-economic impacts of potential changes in the biophysical setting are reported as percent variation in per capita GDP relative to a baseline scenario. Based on such methods, economic impact of climate change is estimated at 2 to 9 percent of annual national GDP for developing countries (IPCC-WGII 1997) in contrast to a 1 to 1.5 percent reduction in GDP for developed countries. The greater vulnerability of poorer regions to climate change is related to their high reliance on weather-related activities, particularly agriculture, and the low adaptation and damage restoration 
capacity (Tol 1996). While there is a growing trend to estimate the impacts on welfare rather than the economy, it is difficult to compare broadly different impacts and to measure them on a single scale, even when the randomness and poor understanding of socio-economic systems are overcome.

It is widely argued that many consequences of climate change are not easily amenable to monetary valuation (IPCC-WGII 1997). Examples of such consequences include loss of human life, loss of natural habitats, species loss, migration, and uneven resources distribution within a single country. Significant variations are noted when monetary valuation of such impacts is undertaken, thus resulting in differences in the estimation of financial losses. The assessment of the impacts of a $2.5{ }^{\circ} \mathrm{C}$ temperature increase due to $\mathrm{CO}_{2}$ concentration doubling on US water resources is an example. Different studies evaluate the damages to range from $6.1 \times 10^{9} \$$ (Cline 1992) to $13.7 \times 10^{9} \$$ (Fankhauser 1995).

Even when the impact assessment is not narrowed down to an economic valuation, the structure of the economy and the related development level and population distribution characteristics are necessary for vulnerability studies. Figure 3 depicts the distribution of the 1998 economic activity between the sectors for the countries under consideration. The sectors considered are the industry, the agriculture and services that encompass everything else (example: banking, tourism). Note that data for Iraq and the Palestinian Authority are not available. After the gulf war, the nascent Iraqi industry was damaged and the economic activity in the country today mainly relies on oil exports, light industries, and agriculture. In addition to the three main sectors, the economic activity in the Palestinian Authority relies heavily on cash flow from workers in Israel as well as external international assistance.

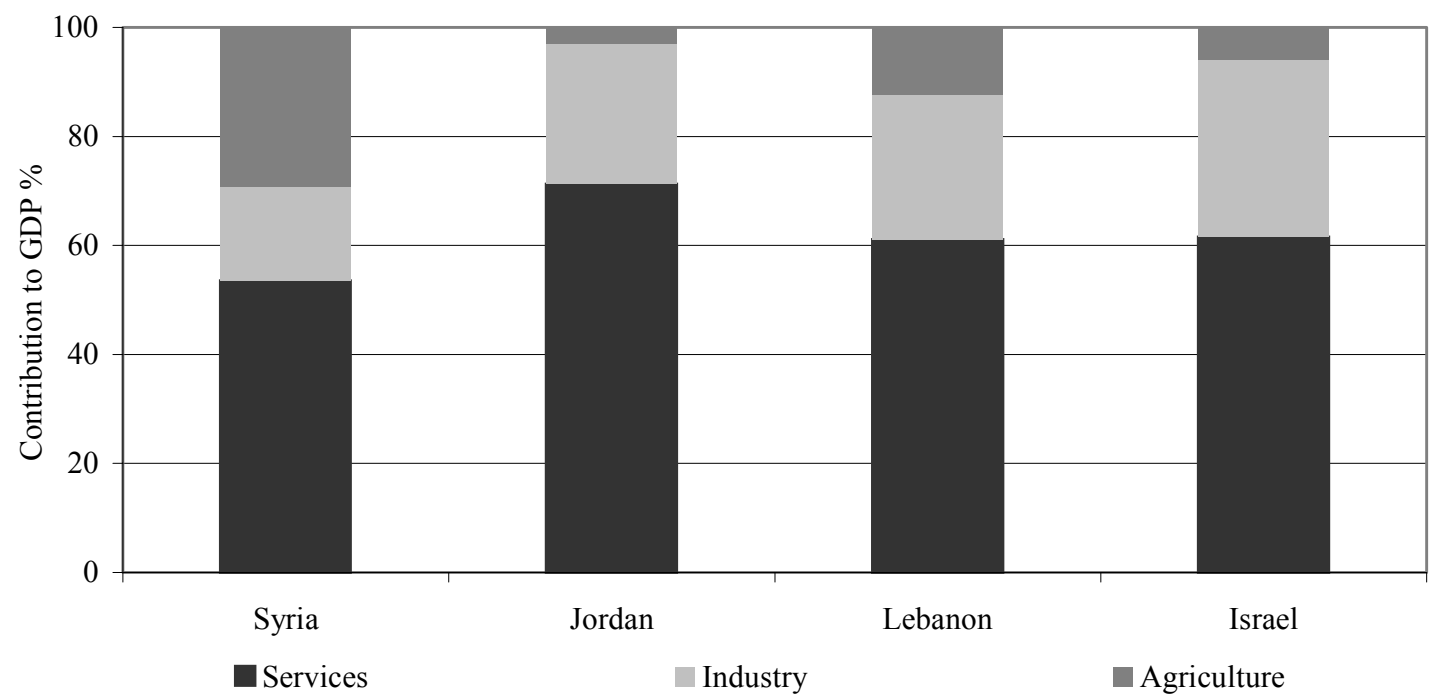

Figure 3. Economic activity by sector (World Bank 1999)

Economic analysis of climate change impacts can be considered at a macroscale (whole national or regional economy), a sectoral scale (economic sectors), or a project scale (effect on economic feasibility of a dam, for example). Water resources variations are assumed to impact water prices and agricultural water demand. Impacts on other economic sectors are usually indirect impact through the use of agricultural product and higher water prices. Since water price elasticity is very difficult to establish; extrapolation of current conditions without regard to potential novelties and discontinuities is often used.

This review will primarily present a qualitative assessment of expected welfare implications of climate change impacts on Middle East water resources. Economic modeling should address each country separately due to the variations in economic activity characteristics and relatively low economic 
integration in the region. Due to the semi-arid weather of the region, water can be a limiting factor for development. This indicates that potential welfare impacts could be high. Even Syria and Iraq that depend heavily on river flow from Turkey, could be seriously affected since trans-boundary water flow is expected to decrease as Turkey attempts to face its own water shortage problems in the future. The climate in Turkey could be characterized as semi-arid in vast regions of the country and demographic growth is expected to increase stress on water resources even if climate change is not considered.

International assessments of climate change impacts on the Middle East region often focus on the oil producing gulf countries. Some studies (Tol 1995) evaluate the cost of coastal defenses, dryland, wetland, and species loss, migration and natural hazards in the region to be insignificant. Other damages are assessed to have very low costs compared to similar costs in other regions of the world. Few studies described the climate change impacts on Middle East countries lying on the Mediterranean basin (Jeftic et al. 1996, IPCC-WGII 1997).

Table 6 summarizes the expected extent of socio-economic impacts associated with climate change effects on water resources accounting for both the importance of the impact (for example, the increased agricultural demand per hectare of agricultural land) and the significance of the impacted sector (for example, the total agricultural water demand and part of the agriculture in the GDP). The assessment is qualitative and relies on literature addressing Middle Eastern countries considered here or countries with some similar characteristics.

Industrial water use is not significantly affected by climate change (Strzepek 1998). Domestic water demand is negatively correlated with water prices and precipitation and positively correlated with ambient temperatures (Kindler and Russel 1984). Temperature rise is expected to be highest in Syria, Iraq and Jordan while precipitation is not expected to be significantly reduced (Table 5). Price variations are very difficult to forecast in the region since market mechanisms do not totally control prices in many of the countries under investigations. In addition, it can be argued that domestic water demand rise do not continually increase with temperatures for countries that already have relatively warm climates. Increase in domestic water demand is not expected to be significant in Jordan, Israel, and the Palestinian Authority since the climate in these countries is already arid and water prices are expected to increase significantly with demand increase. On the other hand, Syria, Iraq and Lebanon are expected to witness some increase in domestic water demand since the length of the dry period in these countries is likely to increase and elasticity of water prices with demand is lesser than for the other counties due to the relatively more abundant water resources.

Increases in agricultural water demand are expected to be significant in all countries. However, the sioco-economic impacts in Jordan are expected to be insignificant since agricultural activity in the country is very minor. Israel is expected to have some moderate impacts due to the low share of agriculture to its GDP (World Bank 1999) and the relatively high adaptation capacity correlated with the high per capita GDP of Israel. Lebanon, Syria, Iraq, and the Palestinian Authority will face harder challenges to mitigate decreased water availability impact on agricultural economy.

Unequal water resources distribution impacts are expected to be most severe for rural populations that rely on agricultural production and on small-scale water management networks (European Parliament 1999). Hence, equity in water distribution is projected to decrease mostly in Syria, Iraq, Jordan, and the Palestinian Authority, where the large rural agricultural populations (Table 2) will be more affected than urban population. Lebanon and Israel have a higher percentage of urban population and less widespread rural populations that could be better served if their local water resources are depleted.

Floods can be divided into two categories: riverine floods (river overflow during thunderstorms or during the snow-melting season) and flash floods (due to severe thunderstorms causing great overland runoff). It is speculated that warmer ambient temperatures and higher evaporation rates will increase flood risk (Dracup and Kendall 1990). Damage is not expected to be significant in Syria, Israel, Jordan, 
and the Palestinian Authority due to scarcity of rivers and the absence of major urban areas in the vicinity of water bodies. Lebanon has high average precipitation, many rivers, and many urban settings near major rivers (Example: the historical flood of the Abu-Ali river in Tripoli, Lebanon). These factors indicate a potential for increased damage from flood events relative to baseline conditions. Iraq has most of its urban and agricultural population (including the capital Bagdad) in the basins of the Tigris and Euphratis rivers and floods in these rivers can cause very significant social and economic damages. However, flood risk in Iraq will be highly dependent on upstream control and Turkish dam projects Alternatively, flood protection works will be costly and will incur economic damage to the country.

Impacts on water quality are very difficult to assess due to uncertainties in predicting the biological, physical, societal, economic, regulatory changes or adaptation measures that could affect the water environment. It is usually agreed that the impacts, if any, are mainly negative (Hanaki et al. 1998; Jacobi 1990). A potentially high impact was noted in Table 6 for all countries since water quality is already a problem in most of these countries and a decrease in water resources is correlated with a lower dilution potential of existing pollution. Even in countries that have significant water treatment capacity, water treatment costs will rise and economic impact will ensue. In addition to economic impacts, water quality deterioration could results in environmental damages and aquatic species loss. Water quality could also be affected by rising sea levels since many countries rely heavily on groundwater resources and groundwater salinity is expected to rise due to an increase in sea water intrusion.

Hydropower loss is usually a concern in regions with high proportion of Hydroelectric to total electric power (Gleick 1990). These proportions are insignificant in all countries since hydropower resources are scarce and untapped in the region. Lebanon is an exception as it has several hydropower plants and plans to build other ones (El-Fadel et al. 2000). However, reduction in hydropower availability in Lebanon are projected to be low to moderate since fossil fuel power generation capacity is growing faster than hydroelectric capacity. If mitigation of GHG emissions reverses this trend, the country might be highly vulnerable to water flow variations.

At the latitude of the Middle East, ecosystem damage and species loss is expected to be most significant in mountainous regions where vegetation distribution is likely to shift to higher altitudes (IPCC-WGI 1997, IPCC-WGII 1997). Hence, insignificant to moderate bioclimatic changes are projected for the studied countries under medium climate change scenarios due to the relatively flat topography of the region. Lebanon and some regions in western Syria are the only areas where such impact can be high due to the mountainous topography and the expected reduction in the areas of many "wet" bioclimatic regions (the Oro-Mediterranean bioclimatic region is one example) that cover large areas in the mountainous regions of the country (UNDP 1999).

Based on ranges reported in literature (IPCC-WGI 1997), potential reduction in GDP due to climate change was projected for the six countries. Reduction is lowest for Israel and Jordan (1 to 2 percent) due to the small contribution of weather exposed activity to the economy. Syria and Iraq could have significant GDP reduction up to 7 percent due to the important reliance on agriculture and a currently low adaptation capacity. Finally, a detailed assessment of the health implications of water resources vulnerability to climate change would be quite complex; however, it is expected that serious health challenges will arise due to increased temperatures and reduced water availability. Propagation of vector-borne diseases and water-borne will be particularly exacerbated due to higher temperatures and extreme weather events (Patz 1999). 
Table 6. Socio-economic implications of climate change impacts on water resources in some Middle East countries

\begin{tabular}{|c|c|c|c|c|c|c|}
\hline Impact & Iraq & Israel & Jordan & Lebanon & $\begin{array}{l}\text { Palestinian } \\
\text { Authority }\end{array}$ & Syria \\
\hline Increased industrial and domestic water demand & ++ & + & + & ++ & + & +4 \\
\hline $\begin{array}{l}\text { Increased agricultural } \\
\text { water demand }\end{array}$ & $+x$ & ++ & + & +4 & $+x$ & +1 \\
\hline $\begin{array}{l}\text { Water resources distribution } \\
\text { equity decline }\end{array}$ & $+x$ & ++ & +4 & +4 & +4 & $x+4$ \\
\hline Flood damage & +4 & + & + & +4 & + & + \\
\hline Water quality damage & +4 & +4 & +4 & +4 & +4 & +ִ+ \\
\hline Hydropower loss & + & + & + & +4 & + & + \\
\hline $\begin{array}{l}\text { Ecosystems damage } \\
\text { and species loss }\end{array}$ & +4 & + & + & +4 & +4 & + \\
\hline GDP reduction (percent) & $3-6$ & $1-2$ & $1-2$ & $2-5$ & $2-5$ & $4-7$ \\
\hline
\end{tabular}

While the analysis provides a prediction of potential climate change impact on water resources in the Middle East, the results can be correlated with several limitations including:

D Climate change scenarios for the region have large uncertainties and discrepancies between the different GCMs. For instance, predictions for the Nile river flow in Egypt varies from a 30 percent increase (GISS model) to a 78 percent decrease (GFDL model) for the same scenario depicting $2 \times \mathrm{CO}_{2}$ conditions (Strzepek and Yates 1996).

$\supset$ A given change in climate will produce different responses in the basins of the Middle East depending on the hydrologic characteristics of each basin. Lack of data about basin characteristics and accurate water balance data hinders the use of advanced hydrologic models.

$\supset$ Baseline predictions are unsure in view of the uncertainty in forecasting socioeconomic, legislative, and water management conditions. Countries that might have low adaptation and mitigation capacity at present might build such capacities at largely different rates.

\section{ADAPTATION MEASURES}

When adaptation measures are usually designed or implemented before climate change, they must be flexible enough to perform their designated objectives under a wide variety of future climate conditions (Smith 1996). Measures that apply to Middle Eastern countries are discussed in the light of the expected increasing stress on water resources in the study region and the potential adverse impacts of climate change. In addition to climate change stress on water resources, water shortages will be exacerbated by population and economic growth. In fact, the baseline scenario predicts a drop in per capita water resources of about 50 percent for the region by 2025. Therefore, most adaptation measures can be qualified as no-regret options. In other words, they would be beneficial regardless of climate change impacts. Moreover, these measures will improve the adaptability of water resources systems to natural variability in climate patterns (Conway and Hulme 1996).

The main adaptation measures and non-conventional sources of water that can be exploited in the future are summarized in Table 7. Adoption of any particular adaptation measure will need capital investment, institutional reforms, and capacity building. Institutional reforms should aim at strengthening institutions, removing market distortions, correcting market failure to reflect environmental damage or resource depletion, and promoting public awareness and involvement. Capacity building would be of crucial importance for monitoring and mitigating the impacts on water quality. In addition to technical adaptation measures, improvement of management systems (coordinating use of river basins, inter-basin transfer, etc.) and development of drought or flood contingency planning are essential to minimize climate change impact on water resources. 
Table 7. Technical adaptation measures and non-conventional water resources

\begin{tabular}{|c|c|c|c|}
\hline Adaptation measure & Potential benefits & Best uses & $\operatorname{Cost}\left(U S \$ /\left(m^{3} \cdot d a y^{-1}\right)\right)$ \\
\hline Conservation & $\begin{array}{l}\text { Curbs water demand } \\
\text { increase }\end{array}$ & $\begin{array}{l}\text { Domestic, industrial, } \\
\text { agricultural demand } \\
\text { reduction }\end{array}$ & $\begin{array}{l}\text { Cost could be negative } \\
\text { if pricing policies are } \\
\text { adopted to reduce } \\
\text { demand }\end{array}$ \\
\hline $\begin{array}{l}\text { Use of surplus winter } \\
\text { runoff }\end{array}$ & $\begin{array}{l}\text { Collectable runoff can } \\
\text { constitute up to } 10 \% \text { of } \\
\text { rainfall }\end{array}$ & $\begin{array}{l}\text { Irrigation, } \\
\text { Aquifer recharge }\end{array}$ & Not available \\
\hline Wastewater reclamation & $\begin{array}{l}\text { All collected wastewater } \\
\text { can be reused }\end{array}$ & $\begin{array}{l}\text { Irrigation, } \\
\text { Aquifer recharge }\end{array}$ & $0.5-1.5$ \\
\hline $\begin{array}{l}\text { Seawater/brackish water } \\
\text { desalination }\end{array}$ & Unlimited water supply & Domestic, industrial & $0.7-1.5$ \\
\hline $\begin{array}{l}\text { Rainfall enhancement by } \\
\text { seeding clouds with } \\
\text { silver iodide crystals }\end{array}$ & $\begin{array}{l}\text { Can increase } \\
\text { precipitation by up to } 15 \\
\text { percent in arid regions }\end{array}$ & $\begin{array}{l}\text { Irrigation, } \\
\text { Aquifer recharge }\end{array}$ & Not available \\
\hline Use of submarine springs & $\begin{array}{l}\text { Submarine springs with } \\
\text { significant flows are } \\
\text { located along the } \\
\text { Lebanese coastal waters } \\
\text { (Ayoub et al. } 2000 \text { ) }\end{array}$ & $\begin{array}{l}\text { Domestic, industrial, } \\
\text { agricultural use, } \\
\text { aquifer recharge }\end{array}$ & Not available \\
\hline
\end{tabular}

\section{CONCLUSION}

The potential impacts of climate change on water resources in the Middle East region were presented. Simulations of climate change predictions from several GCMs were used to evaluate impacts on water resources. Climate change is expected to further exacerbate existing water shortages. Although precipitation was not predicted to decrease, temperature increases of $0.6-2.1{ }^{\circ} \mathrm{C}$ would impact the water balance and reduce available resources. Similar hydrologic impacts might have different socioeconomic consequences depending on region-specific characteristics. In the context of the Middle East, variations in water resources systems might have significant adverse effects including reduction of Gross Domestic Product, population redistribution, work force shift to alternative economic sectors, etc. Several potential welfare impacts were evaluated. The most critical on the regional scale are expected to be: increased agricultural water demand, water resources distribution equity decline, water quality damage, GDP reduction. Serious health implications and increased propagation of diseases could also result from more extreme weather events and higher temperatures. The indirect impact of climate change on hydraulic structures should not be underestimated in view of potential increases in precipitation intensities and modifications in river flows patterns. Adaptation measures are necessary in view of increased water demand and potential decrease in available water. Most adaptation measures are no-regret options that attempt to develop non-conventional sources of water that can be exploited in the future including use of surplus winter runoff, wastewater reclamation, seawater and brackish water desalination, rainfall enhancement by seeding clouds with silver iodide crystals, and exploitation of submarine springs. Conservation measures, as well as institutional reforms and capacity building, are also needed.

\section{ACKNOWLEDGMENTS}

Special thanks are extended to the United States Agency for International Development for its continuous support for the Water Resources Center and the Environmental Engineering and Sciences Programs at the American University of Beirut. 


\section{REFERENCES}

Alatout, S. (2000). Water balances in Palestine: numbers and political culture in the Middle East. in Water Balances in the Eastern Mediterranean. Brooks, D.B. and Mehmet, O. eds., pp. 59-84, International Development Research Center, Ottawa, Ontario, Canada.

Amery H.A. (2000). Assessing Lebanon's water balance. in Water Balances in the Eastern Mediterranean. Brooks, D.B. and Mehmet, O. eds., pp. 13-28, International Development Research Center, Ottawa, Ontario, Canada.

Arnell, N. (1996). Global warming, river flows and water resources. The Institute of Hydrology. John Wiley and Sons, West Sussex, UK.

Ayoub, G., Ghannam, J., Khoury, R., Acra, A., Hamdar, B. (2000). "The submarine springs in the Chekka Bay, Lebanon: Delineation of salient features." International Development Research Center (IDRC), Ottawa, Canada.

Berkoff, J. (1994). "A strategy for managing water in the Middle East and North Africa". The International Bank for Reconstruction and Development, The World Bank, Washington D.C., USA.

Cline, W.R. (1992). The economics of global warming. Institute for International Economics, Washington, D.C.

Conway, D. and Hulme, M. (1996). "The impacts of climate variability and future climate change in the Nile basin on water resources in Egypt." Water Resources Development, 12 (3), 277-296.

Dracup, J.A. and Kendall, D.R. (1990). "Flood and Droughts." In Climate Change and U.S. Water Resources", Waggoner, P.E. ed., John Wiley and Sons, New York.

Economic and Social Commission for Western Asia (ESCWA) (1996). "Water legislation in selected ESCWA countries.” Report E/ESCWA/ENR/1996/WG.1/WP.3, Beirut, Lebanon.

Economic and Social Commission for Western Asia (ESCWA) (1999). "Updating the assessment of water resources in ESCWA member states." Report E/ESCWA/ENR/1999/WG.1/WP.3, Beirut, Lebanon.

El-Fadel, M., Zeinati, M., and Jamali, D. (2000). "Water resources in Lebanon: Characterization, water balance and constraints." Water Resources Development, 16 (4), pp. 619-642, 2000.

"Encyclopaedia Britannica” (1999). <http://www.britanica.com> (Feb. 17, 2000)

Environmental Resources Management (ERM) (1995). "Lebanon: assessment of the state of the environment" Technical Report for World Bank and Ministry of the Environment, Beirut, Lebanon.

European Parliament (1999). "Consequences of Climate Change for Agricultural Production." Publication No. EP/IV/B/STOA/98/02/01, Brussels.

Fankhauser, S. (1995). Valuing climate change, the economics of greenhouse. EarthScan, London.

Food and Agriculture Organization of the United Nations (FAO) (1997). "Irrigation in the Near East region in Figures". Rome, Italy.

Food and Agriculture Organization Statistics Database (FAOSTAT) (1999). <http://apps.fao.org/cgibin/nph-db.pl> (Feb. 16, 2000) 
Gleick P.H. (1990). "Vulnerability of Water Systems." In Climate Change and U.S. Water Resources", Waggoner, P.E. ed., John Wiley and Sons, New York..

Hanaki, K., Takara, K, Hanazato, T, Hiromaru, H, and Kayanne, H. (1998). "Impacts on Hydrology/Water Resources and Water Environment." In Global Warming: The Potential Impact on Japan, Springer-Verlag, Tokyo.

Intergovernmental Panel for Climate Change, Data Distribution Center (IPCC-DCC) (1999). $<$ http://ipcc-dcc.cru.uea.ac.uk>. (Feb. 24, 2000)

Intergovernmental Panel for Climate Change, Working Group I (IPCC-WGI) (1996a). Climate change 1995: The science of climate change, Cambridge University Press, Cambridge, UK.

Intergovernmental Panel for Climate Change, Working Group I (IPCC-WGI) (1996b). IPCC workshop on regional climate change projections for impact assessment. Geneva, Switzerland.

Intergovernmental Panel for Climate Change, Working Group I (IPCC-WGI) (1997). Stabilization of atmospheric greenhouse gases: physical, biological and socio-economic implications. Houghton, J.T., Filho, L.G.M., Griggs, D.J., and Maskell, K. eds. Geneva, Switzerland.

Intergovernmental Panel for Climate Change, Working Group II (IPCC-WGII) (1996). Climate change 1995: Impacts, adaptation and mitigation of climate change, scientific-technical analyses, Cambridge University Press, Cambridge, UK.

Intergovernmental Panel for Climate Change, Working Group II (IPCC-WGII) (1997). The regional impacts of climate change, summary for policymakers. R.T. Watson, M.C. Zinyowera, R.H. Moss, and D.J. Dokken, eds., Geneva, Switzerland

Intergovernmental Panel on Climate Change, Task Group on Scenarios for Climate Impact Assessment (IPCC-TGCIA) (1999). "Guidelines on the use of scenario data for climate impact and adaptation assessment”. Version 1, T.R. Carter, M. Hulme, and M. Lal, eds., Geneva, Switzerland.

International Development Research Center (IDRC) (2000). Water Balances in the Eastern Mediterranean. Brooks, D.B. and Mehmet, O. eds., Ottawa, Ontario, Canada.

International Hydrology Series (IHS) (1999). Impacts of climate change and climate variability on hydrological regimes. J.C. Van Dam, ed., Cambridge University Press, Cambridge, U.K.

Jacobi, H.D. (1990). "Water Quality." In Climate Change and U.S. Water Resources", Waggoner, P.E. ed., John Wiley and Sons, New York.

Jeftic, L., Keckes, S., and Pernetta, J. C. (eds). (1996). Climate Change and the Meditterranean. Arnold, London.

Jones, R.G., Murphy, J.M., Noguer, M., and Keen, A.B. (1997). "Simulation of climate change over Europe using a nested regional-climate model. II: comparison of driving and regional model responses to a doubling of carbon dioxide." Quarterly Journal of the Royal Meteorological Society, 123 (538), $265-$.

Kindler, J. and Russel, C.S. (eds.) (1984). Modeling Water Demands. London: Academy Press.

Lithwick, H. (2000). "Evaluating water balances in Israel." in Water Balances in the Eastern Mediterranean. Brooks, D.B. and Mehmet, O. eds., pp. 29-58, International Development Research Center, Ottawa, Ontario, Canada. 
Lonergan, S.C. and Brooks, D.B. (1994). Watershed: The role of fresh water in the Israeli Palestinian Conflict. International Development Research Center. Ottawa, Ontario, Canada.

Ministry of Foreign Affairs (MFA) (1999). "Spotlight on Israel: Israel chronic water problem." Jerusalem. <http://www.israel-mfa.gov.il/mfa/go.asp?MFAH00ic0> (Aug. 24, 2000).

Patz, J.A. (1999). "Climate change and health: challenges for an interdisciplinary approach". Environmental Management Magazine, Air and Waste Management Association, March, 1999.

Postel, S. (1993). Water scarcity spreading, vital signs. H. Kane, and E. Ayres, eds., WorldWatch Institute, Norton \& Co., New York.

Shannang, E. and Al-Adwan, Y. (2000) "Evaluating water balances in Jordan." in Water Balances in the Eastern Mediterranean. Brooks, D.B. and Mehmet, O. eds., pp. 85-94, International Development Research Center, Ottawa, Ontario, Canada.

Shuval, H. (1994) "Proposals for the integrated management of the shared transboundary water resources of the Jordan River Basin”. Water Science and Technology, 30 (5), 187-193.

Smith, J.B. (1996). "Development of adaptation measures for water resources." Water Resources Development, 12 (2), 151-163.

Star M. (1999). "WATBAL: A model for estimating monthly water balance components, including soil water fluxes". Proc. $8^{\text {th }}$ Annual Report 1999, UN ECE ICP Integrated Monitoring, The Finish Environment 325, 31-35.

Strzepek, K.M. (1998). Handbook on methods for climate change impact assessment and adaptation strategies, chapter 6: water resources. J.F. Feenstra, I. Burton, J.B. Smith, and R.S.J. Tol, eds., United Nations Environment Programme and Dutch Institute for Environmental Studies.

Strzepek, K.M. and Yates, D.N. (1996). "Economic and social adaptations to climate change impacts on water resources: A case study of Egypt.” Water Resources Development, 12 (2), 229-244.

Strzepek, K.M., Yates, D.N., Scheraga, J.D., and Grambsch, A. (1996). "Assessing the economic impacts of climate change: Choosing the right model for the right question." Water Resources Development, 12 (2), 141-150.

Tol R.S.J. (1995). "The damage costs of climate change toward more comprehensive calculation." Environmental Resources Economics, 5, 353-374.

Tol R.S.J. (1996). "The damage costs of climate change towards a dynamic representation." Ecological Economics, 19, 67-90.

United Nations Development Program (UNDP) (1999). "The first national inventory of greenhouse gas emissions by sources and removals by sinks." Ministry of Environment, Beirut, Lebanon.

World Bank (1999). "World Development Indicators 2000.” Development Data, Country Data, Country tables, Lebanon, $131<\mathrm{http} / /$ www.worldbank.org/data/countrydata/countrydata.html> (Aug. 24, 2000). 